\title{
Effects of insecticide and acaricide mixtures on Diaphorina citri control
}

\author{
Jaqueline Franciosi Della Vechia ${ }^{1}$, Daniel Junior de Andrade ${ }^{2}$, \\ Rafael Gomes de Azevedo ${ }^{3}$, Marcelo da Costa Ferreira ${ }^{4}$
}

\begin{abstract}
Pesticide mixtures are commonly used to reduce production costs in agriculture. However, the consequences of such practice towards target organisms are still unknown in most cases. Therefore, this study aimed to evaluate the effects of combinations of insecticides and one worldwide used acaricide on the control of Diaphorina citri (Asian citrus psyllid). All insecticides alone (lambda-cyhalothrin+thiamethoxam, phosmet, and imidacloprid) and in combination with spirodiclofen were efficient in controlling D. citri $(>80 \%)$. No significant effects were found for combinations of lambda-cyhalothrin+thiamethoxam and phosmet insecticides with spirodiclofen. Conversely, imidacloprid caused an antagonistic effect on the control of $D$. citri when mixed with the acaricide. After all, spirodiclofen had no effect on the $\mathrm{pH}$ and electrical conductivity of insecticidal spray solutions. Spirodiclofen mixtures with lambda-cyhalothrin+thiamethoxam and phosmet had no effect on $D$. citri control, but combinations with imidacloprid interfered with it. Index terms: Huanglongbing - HLB; antagonist effect; tank mixture; Asian citrus psyllid; citrus leprosis.
\end{abstract}

\section{Efeito da mistura de inseticidas e acaricida no controle de Diaphorina citri}

Corresponding author: jaque_dellavechia@hotmail.com

Received: July 02,2018 Accepted: October 16, 2018

Copyright: All the contents of this journal, except where otherwise noted, is licensed under a Creative Commons Attribution License.
Resumo - Misturas de agrotóxicos são comumente utilizadas para reduzir os custos de produção na agricultura. No entanto, as consequências de tal prática para organismos-alvo ainda são desconhecidas na maioria dos casos. Portanto, este trabalho teve como objetivo avaliar os efeitos de combinações de inseticidas e um acaricida utilizado mundialmente no controle de Diaphorina citri (psilídeo asiático dos citros). Todos os inseticidas isolados (lambda-cialotrina + tiametoxam, fosmete e imidacloprídeo) e em combinação com o espirodiclofeno foram eficientes no controle de $D$. citri $(>80 \%)$. Não foram encontrados efeitos significativos para combinações de lambdacialotrina + tiametoxam e fosmete com espirodiclofeno. Por outro lado, o imidacloprido causou um efeito antagônico no controle de $D$. citri, quando misturado ao acaricida. Afinal, o espirodiclofeno não teve efeito sobre o $\mathrm{pH}$ e a condutividade elétrica das soluções de pulverização com inseticidas. Misturas de espirodiclofeno com lambda-cialotrina + tiametoxam e fosmete não tiveram efeito sobre o controle de D. citri, mas combinações com imidacloprídeo interferiram nele.

Termos para indexação: Huanglongbing - HLB; efeito antagônico; mistura em tanque; psilídeo asiático dos citros; leprose dos citros.

${ }^{1} \mathrm{PhD}$ student, Department of Crop Protection, São Paulo State University (UNESP), Via de Acesso Prof. Paulo Donato Castellane S/N. Zip: 14.884-900, Jaboticabal, SP, Brazil. E-mail: jaque dellavechia@hotmail.com (ORCID 0000-0001-7648-0627)

${ }^{2} \mathrm{PhD}$ Assistant Professor, Department of Crop Protection, São Paulo State University (UNESP), Via de Acesso Prof. Paulo Donato Castellane S/N. Zip: 14.884-900, Jaboticabal, SP, Brazil. E-mail: danieldwv@yahoo.com.br (ORCID 0000-0003-0054-879X)

${ }^{3}$ Agronomic Engineering, São Paulo State University (UNESP), Via de Acesso Prof. Paulo Donato Castellane S/N. Zip: 14.884-900, Jaboticabal, SP, Brazil. E-mail: rafaelgazevedo@icloud.com (ORCID 0000-0002-5815-4673)

${ }^{4} \mathrm{PhD}$ Titular Professor, Department of Crop Protection, São Paulo State University (UNESP), Via de Acesso Prof. Paulo Donato Castellane S/N. Zip: 14.884-900, Jaboticabal, SP, Brazil. E-mail: mdacosta@fcav.unesp.br 


\section{Introduction}

The Asian citrus psyllid, Diaphorina citri Kuwayama (Hemiptera: Sternorrhyncha: Liviidae), has become one of the main citrus pests worldwide, especially for being a vector of the bacterial disease Huanglongbing (HLB) (HALBERT and MANJUNATH, 2004). Diaphorina citri adults and nymphs can transmit the causal agent of HLB, which is a group of bacteria belonging to the genus Candidatus Liberibacter (XU et al., 1988; PELZ-STELINSKI et al., 2010). As there are still no curative measures for the disease, the management of HLB has been mainly performed by spraying synthetic insecticides against the psyllids (BOINA and BLOOMQUIST, 2015).

After detection in 2004, the control costs of the Brazilian citrus industry have increased significantly, mainly regarding HLB monitoring, eradication of symptomatic plants, and insecticide sprays (TANSEY et al., 2015). Such costs have raised from 12 to $40 \%$ of the total costs for citrus production in Brazil (BELASQUE Jr. et al., 2010).

In this context, new alternatives have been demanded to maintain the economic viability of citrus crops. One of these alternatives consists of using spray tank mixtures, as long as several other pests may occur concomitantly. A very common example is the occurrence of Brevipalpus spp. (Acari: Tenuipalpidae) mites, which are citrus leprosis vectors, along with the Asian citrus psyllid. Notwithstanding the benefits, tank mixtures may also imply numerous adverse effects, such as interferences with physicochemical stability and efficiency of chemicals (REFFSTRUP et al., 2010).

Some pesticide mixtures may change $\mathrm{pH}$, electrical conductivity, spray-solution stability, besides interfering with the biological effect on target organism when compared to the pesticide alone (PETTER et al., 2013).

When combining spinosad and bifenazate, Willmott et al. (2013) found an antagonistic effect for the control of Frankliniella occidentalis (Pergande) (Thysanoptera: Thripidae). Yet Khajehali et al. (2009) verified that, when applied before, chlorpyrifos affected the efficiency of bifenazate, which is an acaricide, used to control Tetranychus urticae Koch (Acari: Tetranychidae).

Moreover, Della Vechia et al. (2018) confirmed a negative effect of acaricide and insecticide mixtures for the control of Brevipalpus yothersi Baker (Acari: Tenuipalpidae). Given the above, it becomes also necessary to verify whether these mixtures can interfere with the control of Asian citrus psyllids and compare combinations with insecticides alone. Thus, this study aimed to investigate the effects of mixtures of different insecticides with a acaricide on $D$. citri control.

\section{Materials and methods}

\section{Diaphorina citri rearing}

To supply insects for bioassays, $D$. citri population was initiated from insects provided by the Fund for Defense of the Citriculture (FUNDECITRUS). Then, these insects were transferred to a greenhouse, at FCAV/ UNESP in Jaboticabal, SP (Brazil), being kept on orange jasmine [Murraya paniculata (L.) Jack] placed inside cages made of voile fabric, a method adapted from Skelley and Hoy (2004).

\section{Residual effect}

We selected three insecticides and one acaricide widely used in citrus production to control $D$. citri and Brevipalpus spp., respectively (TIWARI et al., 2011; VAN LEEUWEN et al., 2015). The insecticides were lambda-cyhalothrin+thiamethoxam $(3.7 \mathrm{~g}$ a.i. per $100 \mathrm{~L}$ water - Engeo Pleno ${ }^{\circledR}$ SC; Syngenta, England), phosmet (175.0 g a.i per $100 \mathrm{~L}$ water - Imidan ${ }^{\circledR} 50 \mathrm{WP}$; Cross Link, Brazil), imidacloprid (4.0 g a.i. per $100 \mathrm{~L}$ water Provado ${ }^{\circledR} 20$ SC; Bayer CropScience AG, Germany). The acaricide was spirodiclofen $(6.0 \mathrm{~g}$ a.i. per $100 \mathrm{~L}$ water - Envidor ${ }^{\circledR} 24$ SC; Bayer CropScience AG, Germany). The concentrations used in this experiment correspond to the highest recommended by manufacturers. As a matter of comparison, the insecticides were tested alone and in combination with the acaricide, and water as a control, so totalizing eight treatments.

Seedlings of Citrus sinensis L. (var. Pera) were grown in 25-L pots filled with soil, sand, and bovine manure $(2: 1: 1 ; \mathrm{v}: \mathrm{v}: \mathrm{v})$, with no pesticide spray. Leaf discs $(3.3 \mathrm{~cm})$ were cut from these plants, being placed on acrylic plates $(35 \times 10 \mathrm{~mm}$; diameter $\times$ height $)$. These plates contained a $1.5 \%$ agar layer in water $(5 \mathrm{~mm})$ for leaf turgescence (as adapted from BARBER et al., 1999).

The pesticides were sprayed on the adaxial surface of leaf discs, applying $2 \mathrm{~mL}$ on the entire surface with the aid of a Potter Tower at $34.5 \mathrm{kPa}$ (Burkard Manufacturing, Rickmansworth, Herts., United Kingdom). The active ingredient concentration in dried residues was about 1.56 $\mathrm{mg} \mathrm{cm}{ }^{-2}$. After leaf discs were dried, 15 D. citri adult females were transferred to each of them. Prior to transfer, the insects were anesthetized with a minimal amount of $\mathrm{CO}_{2}$ (carbon dioxide) for a short period (WENNINGER et al., 2009). With the aid of a sucker device, the insects were transferred to plates, which were wrapped with plastic film (PVC) and kept in a room $\left(25 \pm 2{ }^{\circ} \mathrm{C} ; 65 \% \pm 10 \%\right.$; and $14: 10$ h L: D photoperiod). After 24 and 48 hours of application, mortality rates were evaluated by counting the number of dead and living psyllids.

The experimental design was completely randomized, with eight treatments and five replications, which consisted of one leaf disc each. The experiment was performed twice to confirm the results, being called experiment $\mathrm{A}$ and $\mathrm{B}$. 


\section{Physico-chemical compatibility}

Physical compatibility between pesticides was assessed by a method based on the NBR 13875 (ABNT, 2014). As aforementioned, this experimental design was also completely randomized but with four replications (a $250 \mathrm{~mL}$ beaker each).

The used reagent was standard water with a total hardness of $20 \mathrm{mg} \cdot \mathrm{kg}^{-1}$ in $\mathrm{CaCO}_{3}$ equivalent, prepared according to the NBR 13074 (ABNT, 1997). Solutions were prepared in $250 \mathrm{~mL}$ graduated beakers topped with metallic fabric sieve (149 $\mu \mathrm{m}$ mesh), according to the NBR NM-ISO 3310-1 (ABNT, 2010). Besides that, we used an analytical balance $(0.1-\mathrm{mg}$ resolution) and a graduated pipette for measurements.

Before mixing, all pesticides (insecticides and acaricide) were evaluated individually for dispersion (homogenization). All products used were evaluated at the maximum concentration recommended by the manufacturer (as cited in the previous item). Spray formulations were pipetted with a graduated pipette in beakers. Standard-water samples $(150 \mathrm{~mL})$, previously prepared $\left(20 \mathrm{mg} \cdot \mathrm{kg}^{-1}\right.$ of $\left.\mathrm{CaCO}_{3}\right)$, were added to each beaker prior to pesticides. This beaker was inverted ten times every two seconds for good homogenization. Afterwards, it was completed with standard water up to $250 \mathrm{~mL}$ and inverted ten times again.

Soon after preparation, spray solutions were assessed by checking homogeneity and heterogeneity visually. These patterns consisted of flocculation, sedimentation, phase separation, lumps, oil separation, crystal formation, cream and foam (viscous supernatant layer).

\section{pH and electrical conductivity}

Spray solutions were measured for $\mathrm{pH}$ just before application using a benchtop $\mathrm{pH}$ meter (Q400AS model, Quimis ${ }^{\circledR}$ Company, Diadema, SP - Brazil). The $\mathrm{pH}$ values ranged from 0.00 to 14.00 , and automatic temperature compensation was between 0 and $100{ }^{\circ} \mathrm{C}$, the respective accuracies were \pm 0.02 and $\pm 0.2^{\circ} \mathrm{C}$.

Electrical conductivity was measured with a benchtop conductivity meter (MP11P model, Marth ${ }^{\circledR}$ Company). Before reading, calibration was achieved with standard solutions provided by the manufacturer.

Again, the experiment was carried out in a fully randomized design, with the same treatments mentioned in item 2.2. These treatments were repeated four times, each of which consisted of one reading.

\section{Data analysis}

Data obtained on the first and second day after $D$. citri transfer were used to calculate control efficiency for both treatments using the formula proposed by Abbott (1925), in which mortality rate is corrected for control (only water). Control mortality was similar in both experiments (A and $\mathrm{B}$ ), being of 0 and $6 \%$ after 24 and 48 hours, respectively.

Interactions between insecticides and the acaricide were verified by comparing the observed and expected control efficiency, both alone and in combination. The expected efficiency of combined agents $\left(M_{E}\right)$ was calculated using the formula: $M_{E}=M_{A}+M_{I}\left[\left(1-M_{A}\right) \cdot 100^{-1}\right]$; wherein: $M_{A}$ and $M_{I}$ are respectively the control efficiency of acaricide and insecticide (\%) separately (MORALEZRODRIGUEZ and PECK, 2009).

The interactions were considered additive when mixtures reached a control efficiency equals the sum of each product efficiency; synergistic, when higher than the expected; antagonistic when lower than the expected; and a non-interference when equals that of insecticide alone (REFFSTRUP et al., 2010).

The expected and observed control efficiencies were compared by the Chi-square test $\left(X^{2}\right)$ at $5 \%$ significance. Yet $\mathrm{pH}$ and electrical conductivity values underwent a descriptive analysis with the aid of AgroEstat software (BARBOSA and MALDONADO, 2013).

\section{Results}

The results obtained in both experiments (A and $\mathrm{B}$ ) were similar $(F=4.49 ; p=0.08)$, which enabled evaluating the effects of combinations between the acaricide and each insecticide on D. citri control efficiency (Figures 1 and 2).

Twenty-four hours after application, most of the spray formulations reached a control efficiency above 93.0\% (Figures 1 and 2) except for that with the acaricide alone, which had a $1.70 \%$ efficiency in experiment A and $2.85 \%$ in B. Conversely, spirodiclofen and imidacloprid mixture affected the insecticide performance in both experiments, therefore, showing an antagonistic interaction (Figures 1 and 2, and Tables 1 and 2). Despite imidacloprid, none of the other insecticides was affected by acaricide addition (Figures 1 and 2 and Tables 1 and 2).

Insecticidal spray formulations with the acaricide were physically compatible since there was no sedimentation, phase separation, flocculation, and formation of crystals or lumps, therefore, being homogeneous mixtures. Separately, the $\mathrm{pH}$ values of spray solutions were 6.02 \pm 0.02 (lambda-cyhalothrin+thiamethoxam), $6.09 \pm$ 0.03 (phosmet), $6.08 \pm 0.01$ (imidacloprid), and $6.20 \pm$ 0.05 (spirodiclofen). For mixtures, these values were $5.95 \pm 0.02$ (lambda-cyhalothrin+thiamethoxam and spirodiclofen), $6.31 \pm 0.03$ (phosmet and spirodiclofen), and $6.05 \pm 0.02$ (imidacloprid and spirodiclofen). Electrical conductivity values were $19.19 \pm 0.02$ (lambdacyhalothrin+thiamethoxam), $62.52 \pm 0.09$ (phosmet), 18.58 \pm 0.05 (imidacloprid), and $18.71 \pm 0.11$ (spirodiclofen). For mixtures with spirodiclofen, these values were 19.59 \pm 0.06 (lambda-cyhalothrin+thiamethoxam), $65.32 \pm 0.05$ (phosmet), and $18.87 \pm 0.11$ (imidacloprid). 


\section{Discussion}

The main goal of insecticide and acaricide mixtures is to save operational and financial resources since insects and mites may occur at the same time in citrus orchards. Della Vechia et al. (2018) demonstrated a reduction in control efficiency of $B$. yothersi mites when combining spirodiclofen with phosmet (about $43 \%$ ) and with imidacloprid (about 28\%). Such an outcome was the basis for the development of the present study.

All the treatments containing insecticides were efficient $(>80 \%)$ to control $D$. citri, either alone or in combination with the acaricide. Several studies have already proved the effectiveness of the tested insecticides against Asian citrus psyllid (SANCHES et al., 2009; YAMAMOTO et al., 2009; QURESHI et al., 2014). As already expected, spirodiclofen have no significant insecticidal effect. Richardson and Hall (2013) tested spirodiclofen to control $D$. citri and noted that, right after application, no mortality was observed for nymphs nor did it affect adult longevity; however, as time passed, the authors verified mortality of nymphs. This finding could be explained by the mechanism of action of this acaricide (lipid-synthesis inhibition), in which the time required to cause death is generally higher if compared to other acaricides (MARCIC, 2012).

By contrast, combinations of imidacloprid and spirodiclofen had an antagonistic effect, reducing insecticidal efficiency. Indeed, reductions in the efficiency of $D$. citri control are quite worrisome since they might occur together with an increase in the number of insects contaminated with $\mathrm{Ca}$. Liberibacter (about 70\%) (Manjunath et al. 2008). Distinctly, Poltronieri (2013) observed no effect on imidacloprid efficiency against $D$. citri when mixed with the fungicides thiophanate-methyl, pyraclostrobin, and difenoconazole. In wheat crops, Joshi and Sharma (2009) reported no effect of imidacloprid mixtures with propiconazole for the control of Sitobion avenae (Fabricius) and Rhopalosiphum maidis Fitch, 1856 (Hemiptera: Aphididae).
Notably, pesticide mixtures may affect the physicochemical or even biological characteristics of spray solutions (VAN LEEUWEN et al., 2007; MINTON et al., 2008; REFFSTRUP et al., 2010; PETTER et al., 2013). As a rule, the $\mathrm{pH}$ of spray solutions is associated with an incompatibility between the used chemicals (RAJASEKAR and MALLAPUS, 2017). In this study, however, the $\mathrm{pH}$ of insecticides was not influenced by adding the acaricide. The $\mathrm{pH}$ ranged little in mixtures if compared to the insecticides alone, but still within the expected for a good insecticide performance (from 3.5 to 6.0) (Petroff). This might have been the reason for the lack of physical incompatibility between the tested chemicals.

Electrical conductivity can be altered in insecticides according to spray formulation, which may reduce the biological efficacy of the chemical (RHEINHEIMER and SOUZA, 2000). Nevertheless, both the $\mathrm{pH}$ and electrical conductivity of mixtures remained similar to that of insecticides alone. Therefore, the addition of spirodiclofen to lambda-cyhalothrin, phosmet, and imidacloprid has no influence on the $\mathrm{pH}$ nor electrical conductivity of the studied spray formulations.

Above all, the determinations of $\mathrm{pH}$ and electrical conductivity are important as they influence application efficiency and accelerate pesticide degradation (RAJASEKAR and MALLAPUS, 2017). In addition, the dissociation constant of many chemicals depends on $\mathrm{pH}$, what further influenced the uptake by plant tissues (CUNHA et al., 2017).

We found that imidacloprid efficiency was affected by adding spirodiclofen to spray formulation. By mixing the products, chemical changes and rearrangement of molecules may have occurred, which might have altered insecticide toxicity. Additionally, pesticide mixtures can also modify the activity of enzymes in the target organism, which are responsible for metabolic detoxification and, consequently, reducing the expected insecticide toxicity (REFFSTRUP et al., 2010).

Table 1. Percentage of observed and expected (mean \pm standard error) efficiency in control of Diaphorina citri and chisquare value $\left(\chi^{2}\right)$ of combination of spirodiclofen with lambda-cyhalothrin + thiametoxam, phosmet and imidacloprid 24 and 48 hours after application (Experiment A).

\begin{tabular}{cccccc}
\hline Treatments & \multirow{2}{*}{ Measurement $^{1}$} & \multicolumn{2}{c}{ 24 hours } & \multicolumn{2}{c}{$\mathbf{4 8}$ hours } \\
& Mortality & $\chi^{\mathbf{2}}$ & Mortality & $\chi^{\mathbf{2}}$ \\
\hline Spirodiclofen + Lambda cyhalothrin + & Observed & $97.5 \pm 2.50$ & \multirow{2}{*}{0.06} & $98.57 \pm 1.42$ & \multirow{2}{*}{0.00} \\
thiametoxam & Expected & $99.97 \pm 0.00$ & & $99.92 \pm 0.00$ & \\
Spirodiclofen + Phosmet & Observed & $93.42 \pm 2.11$ & \multirow{2}{*}{0.16} & $98.47 \pm 1.53$ & \multirow{2}{*}{0.05} \\
& Expected & $97.35 \pm 2.62$ & & $99.92 \pm 0.00$ & \\
Spirodiclofen + Imidacloprid & Observed & $93.32 \pm 2.11$ & \multirow{2}{*}{0.44} & $93.32 \pm 2.11$ & \multirow{2}{*}{0.44} \\
\hline
\end{tabular}

${ }^{1}$ Observed $=$ visualized efficiency of insecticide and acaricide applied in combination; expected $=$ sum of the efficiency of each product applied separately. 
Table 2. Percentage of observed and expected (mean \pm standard error) efficiency in control of Diaphorina citri and chisquare value $\left(\chi^{2}\right)$ of combination of spirodiclofen with lambda-cyhalothrin + thiametoxam, phosmet and imidacloprid 24 and 48 hours after application (Experiment B).

\begin{tabular}{cccccc}
\hline \multirow{2}{*}{ Treatments } & \multirow{2}{*}{ Measurement $^{1}$} & \multicolumn{2}{c}{$\mathbf{2 4}$ hours } & \multicolumn{2}{c}{$\mathbf{4 8}$ hours } \\
& Mortality & $\chi^{\mathbf{2}}$ & Mortality & $\chi^{\mathbf{2}}$ \\
\hline Spirodiclofen + Lambda & Observed & $96.0 \pm 4.00$ & \multirow{2}{*}{0.02} & $100.00 \pm 0.00$ & \multirow{2}{*}{0.00} \\
cyhalothrin + thiametoxam & Expected & $97.33 \pm 2.67$ & & $99.98 \pm 0.00$ & \\
Spirodiclofen + Phosmet & Observed & $93.33 \pm 5.16$ & \multirow{2}{*}{0.07} & $97.15 \pm 2.85$ & \multirow{2}{*}{0.07} \\
& Expected & $96.00 \pm 2.67$ & & $99.98 \pm 0.00$ & \\
Spirodiclofen + Imidacloprid & Observed & $92.00 \pm 4.90$ & \multirow{2}{*}{0.64} & $95.73 \pm 2.85$ & \multirow{2}{*}{0.18} \\
& Expected & $100.00 \pm 0.00$ & & $99.98 \pm 0.00$ & \\
\hline
\end{tabular}

${ }^{1}$ Observed $=$ visualized efficiency of insecticide and acaricide applied in combination; expected = sum of the efficiency of each product applied separately.

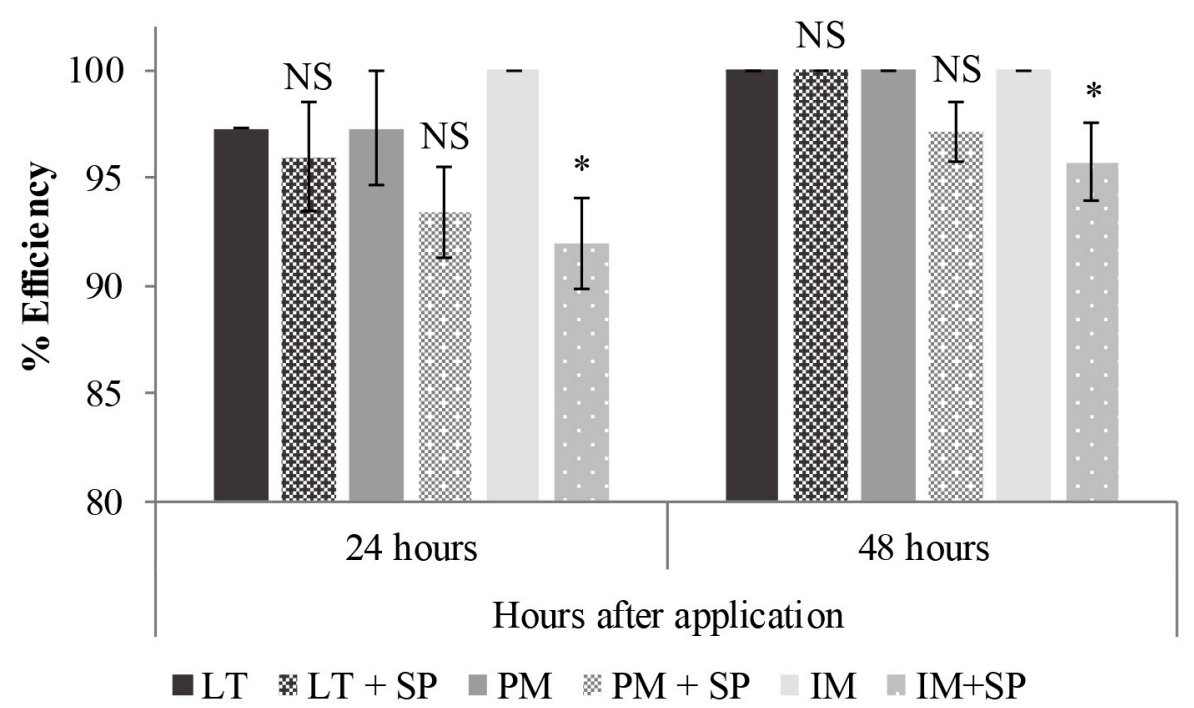

Figure 1. Efficiency (mean \pm standard error) of lambda-cyhalothrin + thiametoxam (LT), phosmet $(\mathrm{PM})$ and imidacloprid (IM), alone and in combination with spirodiclofen (SP)against Diaphorina citri (experiment A).

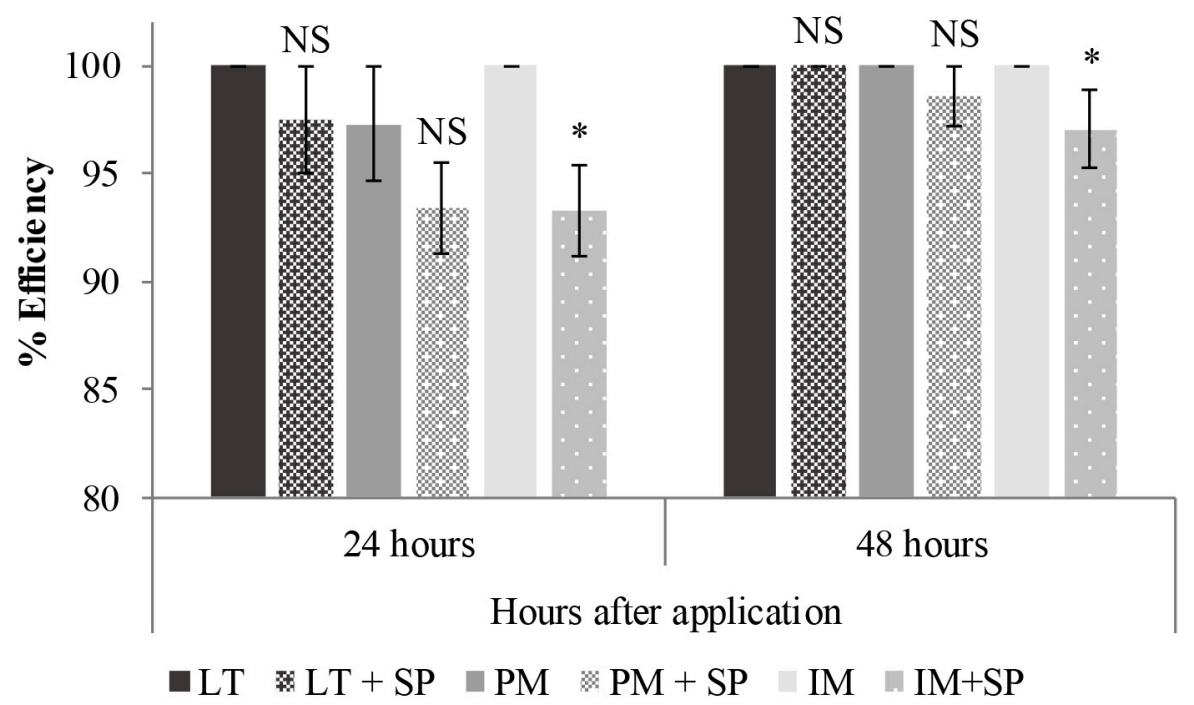

Figure 2. Efficiency (mean \pm standard error) of lambda-cyhalothrin + thiametoxam (LT), phosmet (PM) and imidacloprid (IM), alone and in combination with spirodiclofen (SP) against Diaphorina citri (experiment B). 


\section{Conclusions}

Lastly, the addition of spirodiclofen to lambdacyhalothrin+thiamethoxam and phosmet insecticides caused no interference for control D. citri; however, it compromises the efficiency of imidacloprid. According to our findings, further studies are required to understand how such antagonistic interaction between imidacloprid and spirodiclofen occurs. Another important point is verifying whether acaricide sprays before insecticides also results in such interaction.

\section{References}

ABBOTT, W.S. A method of computing the effectiveness of insecticide. Journal of Economic Entomology, College Park, v. 18, p. 265-267, 1925.

ABNT - Associação Brasileira de Normas Técnicas. NBR 13074: agrotóxicos - preparação de água-padrão para ensaios. Rio de Janeiro, 1997.

ABNT - Associação Brasileira de Normas Técnicas. NBR 13875: agrotóxico - avaliação de compatibilidade físicoquímica. Rio de Janeiro, 2014.

ABNT - Associação Brasileira de Normas Técnicas. NBR NM ISSO 3310-1: Peneiras de ensaio - requisitos técnicos e verificação. Rio de Janeiro, 2010.

BARBER, M.; FIELD, D.; TOPPING, P. The neolithic flint mines of England. Swindon: English Heritage, 1999.

BARBOSA, J.C.; MALDONADO JÚNIOR, W. AgroEstat: sistema para análises estatísticas de ensaios agronômicos. Jaboticabal, FCAV/UNESP, 2013.

BELASQUE JÚNIOR, J.; YAMAMOTO, P.T.; MIRANDA, M.P.; BASSANEZI, R.B.; AYRES, A.J.; BOVÉ, J.M. Controle do huanglongbing no Estado de São Paulo, Brasil. Citrus Research \& Technology, Cordeirópolis, v.31, p.53-64, 2010.

BOINA, D.R.; BLOOMQUIST, J.R. Chemical control of the Asian citrus psyllid and of Huanglongbing disease in citrus. Pest Management Science, West Sussex, v.71, p.808-823, 2015.

CUNHA, J.P.A.R.; ALVES, G.S.; MARQUES, R.S. Tensão superficial, potencial hidrogeniônico e condutividade elétrica de caldas de produtos fitossanitários e adjuvantes. Revista Ciência Agronômica, Ceará, v.48, p.261-270, 2017.
DELLA VECHIA, J.F.; FERREIRA, M.C.; ANDRADE, D.J. Interaction of spirodiclofen with insecticides for the control of Brevipalpus yothersi in citrus. Pest Management Science, West Sussex, v.74, p.11, p.24382443, 2018.

HALBERT, S.E.; MANJUNATH, K.L. Asian citrus psyllids (Sternorrhyncha: Psyllidae) and greening disease of citrus: A literature review Halbert \& ManjunathDiaphorina citri and citrus greening disease. Florida Entomologist, Gainesville, v. 87, p. 330-353, 2004.

JOSHI, N.K.; SHARMA, V.K. Efficacy of imidacloprid (Confior $200 \mathrm{SL}$ ) against aphids infesting wheat Crop. Journal of Central European Agriculture, Zagreb, v.10, p.217-222, 2009.

KHAJEHALI, J.; VAN LEEUWEN, T.; TIRRY, L. Susceptibility of an organophosphate resistant strain of the two-spotted spider mite (Tetranychus urticae) to mixtures of bifenazate with organophosphate and carbamate insecticides. Experimental Applied Acarology, Amsterdam, v.49, p.185-192, 2009.

MANJUNATH, K.L.; HALBERT, S.E.; RAMADUGU, C.; WEBB, S.; LEE, R.F. Detection of 'Candidatus Liberibacter asiaticus' in Diaphorina citri and its importance in the management of citrus huanglongbing in Florida. Phytopathology, Ithaca, v. 98, p. 387-396, 2008.

MARCIC D. Acaricides in modern management of plantfeeding mites. Journal of Pest Science, Berlim, v. 83, p. 395-408, 2012.

MINTON, B.; MATOCHA, M.; SENSEMAN, D. The influence of malathion on trifloxysulfuron absorption and translocation in cotton. Journal of Cotton Science, Cordova, v.12, p.48-52, 2008.

MORALES-RODRIGUEZ, A.; PECK, D.C. Synergies between biological and neonicotinoid insecticides for the curative control of the white grubs Amphimallon majale and Popillia japonica. Biological Control, San Diego, v.51, p.169-180, 2009.

PELZ-STELINSKI, K.S.; BRLANSKY, R.H.; EBERT, T.A.; ROGERS, M.E. Transmission parameters for Candidatus Liberibacter asiaticus by Asian citrus psyllid (Hemiptera: Psyllidae). Journal of Economic Entomology, College Park, v.103, p.1531-1541, 2010.

PETROFF, R. Water quality and pesticide performance. Disponível em: $\leq \mathrm{http}: / / w w w . m o n t a n a . e d u />$. Acesso em: 14 Jan. 2017. 
PETTER, F.A.; SEGATE, D.; ALMEIDA, F.A.; ALCÂNTARA NETO, F.; PACHECO, L.P. Incompatibilidade física de misturas entre inseticidas e fungicidas. Comunicata Scientiae, Piauí, v. 4, p. 129$138,2013$.

POLTRONIERI, A.S. Bases para o manejo da resistência de Diaphorina citri (Hemiptera: Liviidae) ao inseticida neonicotinoide imidacloprid em pomares de citros. 132 f. Tese (Doutorado em Entomologia) - Escola Superior de Agricultura "Luiz de Queiroz", Universidade de São Paulo, Piracicaba, 2013.

QURESHI, J.A.; KOSTYK, B.C.; STANSLY, P.A. Insecticidal suppression of Asian citrus psyllid Diaphorina citri (Hemiptera: Liviidae) vector of Huanglongbing pathogens. Plos One, San Francisco, v. 9, p. 1-22, 2014.

RAJASEKAR, B.; MALLAPUS, C.P. Physical compatibility of agro-chemicals in laboratory. Journal of Pharmacognosy and Phytochemistry, New Delhi, v. 6, p. 273-275, 2017.

REFFSTRUP, T.K.; LARSEN, J.C.; MEYER, O. Risk assessment of mixtures of pesticides. Current approaches and future strategies. Regulatory Toxicology and Pharmacology, New York, v.56, p.174-192, 2010.

RHEINHEIMER, D. S.; SOUZA, R.O. Condutividade elétrica e acidificação de águas usadas na aplicação de herbicidas no Rio Grande do Sul. Ciência Rural, Santa Maria, v.30, p.97-104, 2000.

RICHARDSON, M.L.; HALL, D.G. Toxicity of 6 miticides to the Asian citrus psyllid, Diaphorina citri (Hemiptera: Liviidae). Florida Entomologisty, Florida, v.96, p.433-441, 2013.

SANCHES, A.L.; FELIPPE, M.R.; CARMO, A.U.; RUGNO, G.R.; YAMAMOTO, P.T. Eficiência de inseticidas sistêmicos, aplicados em mudas cítricas, em pré-plantio, no controle de Diaphorina citri (Kuwayama) (Hemiptera: Psyllidae). BioAssay, Piracicaba, v.4, p.1-7, 2009.

SKELLEY, L.H.; HOY, M.A. A synchronous rearing method for the Asian citrus psyllid and its parasitoid in quarantine. Biological Control, San Diego, v.29, p.1423, 2004.
TANSEY, J.A.; JONES, M.M.; VANACLOCHA, P.; ROBERTSON, J.; STANSLY, P. Costs and benefits of frequent low-volume applications of horticultural mineral oil for management of Asian citrus psyllid, Diaphorina citri Kuwayama (Hemiptera: Psyllidae). Crop Protection, Guildford, v.76, p.59-67, 2015.

TIWARI, S.; MANN, R.S.; ROGERS, M.E.; STELINSKI, L.L. Insecticide resistance in field populations of Asian citrus psyllid in Florida. Pest Management Science, West Sussex, v.64, p.1258-1268, 2011.

VAN LEEUWEN, T.; TIRRY, L.; YAMAMOTO, A.; NAUEN, R.; DERMAUW, W. The economic importance of acaricides in the control of phytophagous mites and an update on recent acaricide mode of action research. Pesticide Biochemistry Physiology, San Diego, v.121, p.12-21, 2015.

VAN LEEUWEN, T.; VAN POTTELBERGE, S.; NAUEN, R.; TIRRY, L. Organophosphate insecticides and acaricides antagonise bifenazate toxicity through esterase inhibition in Tetranychus urticae. Pest Managment Science, West Sussex, v.63, p.1172-1177, 2007.

WENNINGER, E.J.; STELINSKI, L.L.; HALL, D.G. Relationships between adult abdominal color and reproductive potential in Diaphorina citri (Hemiptera: Psyllidae). Annals of the Entomological Society of America, College Park, v.102, p.476-483. 2009.

WILlMOTT, A.L.; CLOYD, R.A.; ZHU, K. Efficacy of pesticides mixtures against the western flower thrips (Thysanoptera: Thripidae) under laboratory and greenhouse conditions. Journal of Economic Entomology, College Park, v.106, p.247-256, 2013.

XU, C.F.; XIA, Y.; LI, K.B.; KE, C. Further study of the transmission of citrus huanglongbing by a psyllid, Diaphorina citri Kuwayama. In: CONFERENCE OF THE INTERNATIONAL ORGANIZATION OF CITRUS VIROLOGISTS, 10., 1998, Riverside. Proceedings... p. 243-248.

YAMAMOTO, P.T.; FELIPPE, M.R.; SANCHES. A.L.; COELHO, J.H.C.; GARBIM, L.F.; XIMENES, N.L. Eficácia de inseticidas para o manejo de Diaphorina citri Kuwayama (Hemiptera: Psyllidae) em citros. BioAssay, Piracicaba, v.4, p.1-9. 2009. 